\title{
EFFECTS OF ARGININE AND TREHALOSE ON POST-THAWED BOVINE SPERM QUALITY
}

Caner ÖZTÜRK ${ }^{1 *}$, Şükrü GÜNGÖR ${ }^{2}$, Mehmet Bozkurt ATAMAN ${ }^{3}$, Mustafa Numan BUCAK $^{3}$, Nuri BASSPINAR ${ }^{4}$, Pinar ILI $I^{5}$ and Muhammed Enes INANÇ ${ }^{2}$

${ }^{1}$ Department of Reproduction and Artificial Insemination, Faculty of Veterinary Medicine, Aksaray University, Aksaray, Turkey; ${ }^{2}$ Department of Reproduction and Artificial Insemination, Faculty of Veterinary Medicine, Mehmet Akif Ersoy University,

Burdur, Turkey; ${ }^{3}$ Department of Reproduction and Artificial Insemination and

${ }^{4}$ Department of Biochemistry, Faculty of Veterinary Medicine, Selcuk University, Konya, Turkey; ${ }^{5}$ Department of Medical Services and Techniques/Medical Laboratory Techniques Pr, Denizli Health Services Vocational High School, Pamukkale University, Denizli, Turkey

(Received 19 September 2016; accepted 4 April 2017)

The present study was conducted to examine the protective role of arginine and trehalose on post-thaw bull sperm and oxidative stress parameters. Five ejaculates for each bull were used in the study. Each ejaculate, split into three equal aliquots and diluted at $37^{\circ} \mathrm{C}$ with base extenders containing $2 \mathrm{mM}$ arginine, $25 \mathrm{mM}$ trehalose and no antioxidant (control) was cooled to $5^{\circ} \mathrm{C}$ and then frozen. Frozen straws were thawed in a water bath for evaluation. Supplementation of the semen extender with arginine decreased the percentages of post-thawed subjective motility $(29 \pm 8.21 \%)$, CASA motility $(12.2 \pm 5.69 \%)$ and progressive motility $(3.52 \pm$ $2.13 \%)$, compared with the controls $(43 \pm 2.73 \%, 55.4 \pm 6.78 \%$ and $33.48 \pm$ $4.14 \%$, respectively, $\mathrm{P}<0.05$ ). Supplementation of the semen extender with trehalose produced a higher mitochondrial activity and sperm viability $(36.3 \pm$ $3.99 \%$ and $44.1 \pm 2.18 \%)$ compared with the control $(13 \pm 8.15$ and $31.7 \pm 3.94 \%$, respectively, $\mathrm{P}<0.05)$. It was established that trehalose $(95.1 \%)$ and arginine (92.8\%) protect DNA integrity compared to the control (90.4\%) $(\mathrm{P}<0.05)$. Trehalose supplementation in semen extenders provided great benefit in terms of viability, mitochondrial activity, and intact sperm DNA on frozen-thawed bull sperm.

Key words: Arginine, bull sperm, COMET, fluorescent staining, trehalose, oxidative stress

Sperm production is an important factor influencing the reproductive capacity of males of economically important species (Berndtson, 2008). The application of artificial insemination (AI) has been shown to have the ability to disseminate genes from super genetic males for improving productive characteristics (El-Sheshtawy et al., 2015).

\footnotetext{
"Corresponding author; E-mail: canerozturkvt@gmail.com
} 
Sperm cryopreservation contributes to the expansion of reproductive techniques, such as AI and in vitro fertilisation (Gholami et al., 2010). The factor most affecting conception rate is the quality of frozen semen. The composition of the extender in which semen is diluted before freezing is one of the most important factors affecting cryopreservation (El-Sheshtawy et al., 2015). Mammalian spermatozoa have very specific lipid composition and a high ratio of polyunsaturated fatty acids. This unconventional structure of the sperm membrane is responsible for its flexibility and the functional skill of sperm cells. However, the lipids of spermatozoa are the main cause of peroxidation, which may cause severe functional disorders of sperm. Oxidative stress can cause pathological lipid peroxidation of the sperm membrane (Sanocka and Kurpisz, 2004). Cryopreservation induces damage to spermatozoa that may result in loss of motility, plasma membrane integrity, and fertilising capacity (Aitken et al., 1998).

Oxidative stress can induce DNA fragmentation in the sperm cell (Aitken et al., 2009), and artificially created oxidative stress can induce DNA damage (Aitken et al., 1998). During cryopreservation the level of reactive oxygen species (ROS) generation in the spermatozoa increases (Wang et al., 1997) and this leads to cryo-injury to sperm DNA (Thomson et al., 2009b).

Cryopreservation causes cold shock, oxidative stress, osmotic changes and lipid-protein reorganisations within the cell membranes, thus inducing cell damage (Bailey et al., 2000). L-arginine is often referred to as a nonessential amino acid. This amino acid found in the seminal plasma has an important role in spermatozoal metabolism and motility. L-arginine plays an important role in modulating host defence and cellular immunity (Patel et al., 1998). Sugars have a function in protecting the post-thaw viability of sperm cells. Sugars such as raffinose and trehalose have a cryoprotective role by decreasing intracellular ice crystal formation, thus maintaining the osmotic balance of the diluent (Garde et al., 2008).

Trehalose is a non-penetrating disaccharide, which has a protective action on cells both by increasing the tonicity of the extender and by stabilising the plasma membrane, possibly due to specific interactions with head groups of membrane phospholipids (Crowe et al., 1987). Trehalose inserts itself into the membrane phospholipids bilayer, thus modulating membrane fluidity and therefore rendering the membrane more stable during freezing (Aboagla and Terada, 2003). The positive effect of trehalose has reported by many authors in different species, such as ram (Tonieto et al., 2010), goat (Aboagla and Terada, 2003) and bull (El-Sheshtawy et al., 2015).

The aim of this study was to determine the effects of arginine and trehalose on sperm motility, viability, acrosome integrity, mitochondrial activity, DNA integrity, lipid peroxidation (LPO) and total antioxidant activity (AOP) on bull semen. 


\section{Materials and methods}

\section{Animals and semen collection}

Five healthy Holstein bulls (3-4 years of age) housed at a private dairy farm in Konya and maintained with standard feeding and management practices were used. Semen of these bulls was collected twice a week with the aid of an artificial vagina. In total, 25 ejaculates (five ejaculates from each bull) were collected. Sperm motility was estimated subjectively using phase-contrast microscopy with a warm stage maintained at $37^{\circ} \mathrm{C}$ at $\times 400$ magnification. Only ejaculates having $\geq 80 \%$ sperm motility and concentrations higher than $800 \times 10^{6}$ spermatozoa $/ \mathrm{ml}$ were cryopreserved. After collection, the ejaculates were immersed in a warm water bath at $34{ }^{\circ} \mathrm{C}$. The ejaculates were pooled to balance the sperm contribution of each bull.

\section{Semen processing}

The pooled semen was divided into three equal fractions and diluted to a final concentration of 80 million spermatozoa $/ \mathrm{ml}$ with a Tris-based extender [Tris $297.58 \mathrm{mM}$, citric acid $96.32 \mathrm{mM}$, fructose $82.66 \mathrm{mM}$, egg yolk 15\% (v/v), glycerol $5 \%(\mathrm{v} / \mathrm{v}), \mathrm{pH} 6.8]$ used as the base extender (freezing extender). Each mixed ejaculate was split into three equal aliquots and diluted at $37^{\circ} \mathrm{C}$ with base extenders containing $2 \mathrm{mM}$ arginine and $25 \mathrm{mM}$ trehalose, and no antioxidant (control). Diluted semen samples were loaded into 0.25 -ml (medium-sized) plastic straws, sealed with polyvinyl alcohol powder, and equilibrated at $5{ }^{\circ} \mathrm{C}$ for $2 \mathrm{~h}$. After equilibration, the straws were frozen in liquid nitrogen vapour, $4 \mathrm{~cm}$ above the liquid nitrogen, for $15 \mathrm{~min}$ and plunged into liquid nitrogen for storage. After storage for 1 month, the frozen straws were thawed individually at $37^{\circ} \mathrm{C}$ for $20 \mathrm{~s}$ in a water bath for microscopic evaluation.

\section{Evaluation of microscopic sperm parameters}

To analyse sperm motility and various kinematic parameters the Sperm Class Analyzer $\left(\mathrm{SCA}^{\circledR}\right)$ CASA system (Microptic S.L., Barcelona, Spain) was used. A 5- $\mu 1$ sample of diluted semen was put onto a pre-warmed slide covered with a coverslip and sperm motility characteristics were determined with a $10 \times$ objective at $37{ }^{\circ} \mathrm{C}$. The following motility values were recorded: motility (\%), progressive motility (\%), total sperm motility, VAP (average path velocity, $1 \mu \mathrm{m} \mathrm{s}^{-1}$ ), VSL (straight linear velocity, $1 \mu \mathrm{m} \mathrm{s}^{-1}$ ), VCL (curvilinear velocity, $1 \mu \mathrm{m} \mathrm{s}^{-1}$ ), ALH (amplitude of lateral head displacement, $1 \mu \mathrm{m}$ ) and LIN [linearity index, $\mathrm{LIN}=(\mathrm{VSL} / \mathrm{VCL}) \times 100]$. For each evaluation, seven microscopic fields, each including at least 250 cells, were analysed. 


\section{Assessment of sperm plasma membrane integrity (viability)}

This assessment was performed by staining with a sperm viability kit (SYBR-14/PI Molecular Probe: L 7011 Invitrogen, Carlsbad, CA, USA). The staining protocol was modified from a study of Garner and Johnson (1995). Thawed straws were diluted 1:3 with Tris stock solution without glycerol and egg yolk, and then $30 \mu \mathrm{l}$ of the diluted semen was mixed with $6 \mu \mathrm{l}$ of SYBR-14 and $2.5 \mu \mathrm{l}$ of propidium iodide (PI). The sample was gently mixed, incubated at $37^{\circ} \mathrm{C}$ in the dark for $20 \mathrm{~min}$ and then $10 \mu \mathrm{l}$ of Hancock's solution was added for semen fixation. A wet mount was made using a $2.5 \mu \mathrm{l}$ drop of the sample placed directly onto a microscope slide and covered with a cover slip.

\section{Assessment of sperm acrosome integrity}

Sperm acrosome status was assessed using fluorescein isothiocyanate conjugated to Arachis hypogaea (peanut) (L7381 FITC-PNA, Sigma-Aldrich Co., St. Louis, MO, USA) and by PI staining as described by Nagy et al. (2003) with modifications. Thawed straws were diluted 1:3 with Tris stock solution without glycerol and egg yolk, and then $60 \mu 1$ of the diluted semen was mixed with $10 \mu 1$ of FITC-PNA and $2.5 \mu \mathrm{l}$ of PI. The sample was gently mixed, incubated at $37^{\circ} \mathrm{C}$ in the dark for $20 \mathrm{~min}$ and $10 \mu \mathrm{l}$ of Hancock's solution was added for semen fixation. A wet mount was made using a $2.5 \mu \mathrm{l}$ drop of the sample placed directly onto a microscope slide and covered with a cover slip.

\section{Assessment of sperm mitochondrial activity}

Sperm mitochondrial activity was assessed with a staining protocol modified from Garner et al. (1997). Thawed straws were diluted 1:3 with Tris stock solution without glycerol and egg yolk, and then $300 \mu \mathrm{l}$ of the diluted semen was mixed with $2.5 \mu \mathrm{JC}-1$ and $2.5 \mu \mathrm{PI}$. The sample was gently mixed, incubated at $37^{\circ} \mathrm{C}$ in the dark for $20 \mathrm{~min}$ and $10 \mu 1$ of Hancock's solution was added for semen fixation. A wet mount was made using a $2.5 \mu 1$ drop of the sample placed directly onto a microscope slide and covered with a cover slip.

\section{Assessment of sperm DNA integrity}

Sperm DNA integrity was investigated using the single cell gel electrophoresis (COMET) assay, which is generally performed under neutral conditions. Our method was similar to several protocols applied in previous studies and involved few modifications (Duty et al., 2002; Li et al., 2008). The straws were thawed by gentle shaking in a $37^{\circ} \mathrm{C}$ water bath for $10 \mathrm{~s}$, and centrifuged once at $600 \mathrm{~g}$ for $10 \mathrm{~min}$ at $4{ }^{\circ} \mathrm{C}$. The remaining sperm cells were washed with PBS $\left(\mathrm{Ca}^{2+}\right.$ - and $\mathrm{Mg}^{2+}$-free $)$. Each pre-cleaned slide was pre-coated with a layer of $1 \%$ normal melting point agarose in PBS $\left(\mathrm{Ca}^{++}\right.$-and $\mathrm{Mg}^{++}$-free $)$and then dried at 
room temperature. Approximately 100,000 sperm cells $(18 \mu \mathrm{l})$ were mixed with $0.75 \%$ low melting point agarose $(50 \mu \mathrm{l})$ at $37^{\circ} \mathrm{C}$, and this suspension was poured onto the first agarose layer. The slides were allowed to solidify for $20 \mathrm{~min}$ at $4{ }^{\circ} \mathrm{C}$. The coverslips were removed, and the slides were immersed in freshly prepared cold lysis buffer. The slides were then incubated at $37^{\circ} \mathrm{C}$ in lysis buffer with $20 \mu \mathrm{g} \mathrm{ml}^{-1}$ of proteinase $\mathrm{K}$ for $2 \mathrm{~h}$. The slides were removed from the lysis buffer, drained and placed into a horizontal electrophoresis unit filled with fresh neutral electrophoresis buffer at $4{ }^{\circ} \mathrm{C}$ for a 20 -min incubation to allow the DNA to unwind. Electrophoresis was performed at room temperature, at $25 \mathrm{~V}$ for $20 \mathrm{~min}$. Following electrophoresis, the slides were air-dried, stained with $50 \mu 1$ of $8 \mu 1$ $\mathrm{ml}^{-1}$ ethidium bromide, and covered with a coverslip. The images of $200 \mathrm{ran}-$ domly chosen nuclei per sample were analysed visually. Observations were made at a magnification of $\times 400$ using a fluorescence microscope (Olympus, Japan). Damage was detected by a tail of fragmented DNA that migrated from the sperm head, causing a 'comet' pattern, whereas whole sperm heads, without a comet, were considered to be undamaged.

\section{Oxidative stress parameters}

Briefly, thawed semen samples were centrifuged at $800 \mathrm{~g}$ for $20 \mathrm{~min}$ at $4{ }^{\circ} \mathrm{C}$ to separate the cells from the diluted seminal plasma, and spermatozoa were washed twice with PBS at $800 \mathrm{~g}$ for $20 \mathrm{~min}$. After centrifugation, the supernatant was discarded and the pellet was completed to $500 \mu \mathrm{l}$ with PBS. Subsequently, the sperm suspension was transferred into a $2 \mathrm{ml}$ beaker filled with ice water and sonicated with a probe (Bandelin Sonopuls, Bandelin Electronic, Gerate-Typ: UW 2070, Pro-Nr. 51900037369.004, Berlin) for $10 \mathrm{~s}$ on ice, such that the process was repeated six times at intervals of $30 \mathrm{~s}$ to separate the sperm head and tail. For LPO analysis, $10 \mu \mathrm{l}$ of $0.5 \mathrm{mM}$ butyl-hydroxytoluene (BHT) was added to $120 \mu \mathrm{l}$ of the homogenate samples and stored at $-86^{\circ} \mathrm{C}$ until analysis. The remaining homogenate was centrifuged at $8000 \mathrm{~g}$ for $15 \mathrm{~min}$ at $+4{ }^{\circ} \mathrm{C}$ and the supernatant was collected and stored at $-86^{\circ} \mathrm{C}$ for total antioxidant activity (AOP) analysis.

\section{Determination of lipid peroxidation (LPO) level}

LPO level was determined using commercial kits of LPO 586TM Oxis Research (Oxis Research ${ }^{\mathrm{TM}}$, Bioxytech, CA, USA) by spectrophotometry (UV 2100 UV-VIS Recording Spectrophotometer, Shimadzu, Japan). The assay is based on the reaction of a chromogenic reagent, N-methyl-2-phenylindole with MDA and 4-hydroxyalkenals (LPO) at $45^{\circ} \mathrm{C}$. One molecule of either MDA or 4hydroxyalkenal reacts with two molecules of N-methyl-2-phenylindole in acetonitrile, to yield a stable chromophore with maximal absorbance at $586 \mathrm{~nm}$. The results are expressed as $\mu \mathrm{mol}$ for $10^{9}$ cells $\mathrm{ml}^{-1}$. 


\section{Determination of total antioxidant activity (AOP)}

AOP activity was determined with an AOP-490TM Oxis Research kit (Oxis Research ${ }^{\mathrm{TM}}$, Bioxytech) by spectrophotometry. The assay was based on the reduction of $\mathrm{Cu}^{++}$to $\mathrm{Cu}^{+}$by the combined action of all the antioxidants present in the sample. A chromogenic reagent, bathocuproine (2,9-dimethyl-4,7-diphenyl1,10-phenanthroline), selectively forms a $2: 1$ complex with $\mathrm{Cu}^{+}$, which has a maximum absorbance at $490 \mathrm{~nm}$. A standard of known uric acid (a water-soluble antioxidant) concentration is used to create a calibration curve. The results are expressed as mmol for $10^{9} \mathrm{cells} \mathrm{m}^{-1}$.

\section{Statistical analysis}

Results were expressed as mean \pm SEM. Sperm motility, motion characteristics and abnormality were analysed by analysis of variance, followed by Tukey's post hoc test to determine significant differences between the groups. Spermatozoa with damaged DNA were evaluated by the chi-square test. Differences with values of $\mathrm{P}<0.05$ were considered to be statistically significant. Statistical analyses were performed by using the SPSS 21 package programme.

\section{Results}

Supplementation of the semen extender with arginine decreased the percentages of post-thawed subjective motility $(29 \pm 8.21)$, computer-assisted sperm analysis (CASA) motility $(12.2 \pm 5.69)$ and progressive motility $(3.52 \pm 2.13)$, compared with the controls $(43 \pm 2.73,55.4 \pm 6.78$ and $33.48 \pm 4.14 \%$, respectively, $\mathrm{P}<0.05)$. Trehalose increased the percentages of post-thawed subjective motility $(50 \pm 3.53)$, CASA motility $(64.7 \pm 6.79 \%)$ and progressive motility $(34.36 \pm 4.77)$, compared with the controls $(43 \pm 2.73,55.4 \pm 6.78$ and $33.48 \pm$ $4.14 \%$, respectively, $\mathrm{P}>0.05$ ) (Table 1). Significant differences were observed between the arginine and the control groups for sperm motion characteristics $(\mathrm{P}<0.05)$ except for the ALH value. Arginine provided a lower VAP $(43.8 \pm$ $3.37 \mu \mathrm{m} / \mathrm{s})$, VSL $(29.9 \pm 3.35 \mu \mathrm{m} / \mathrm{s})$, VCL $(81.4 \pm 4.93 \mu \mathrm{m} / \mathrm{s})$ and LIN $(36.82 \pm$ $3.46 \%)$ in comparison to the control group $(74 \pm 6.74 \mu \mathrm{m} / \mathrm{s}, 59.5 \pm 6.06 \mu \mathrm{m} / \mathrm{s}$, $105.7 \pm 9.44 \mu \mathrm{m} / \mathrm{s}, 56.3 \pm 1.71 \%, \mathrm{P}<0.05$ ) (Table 2). Trehalose increased sperm viability, mitochondrial activity and DNA integrity $(44.1 \pm 2.18,36.3 \pm 3.99$ and $95.1 \%$, respectively), compared with those of the control group (31.7 \pm 3.94 , $13 \pm 8.15,90.4 \%, \mathrm{P}<0.05)$ (Table 3$)$. Arginine decreased sperm viability $(22.1 \pm$ 3.28) despite protecting DNA integrity (92.8\%) compared to the control group $(31.7 \pm 3.94 \%, \mathrm{P}<0.05)$ (Table 3). No significant differences were observed between the groups for sperm acrosome integrity $(\mathrm{P}>0.05)$ (Table 3$)$. In the comet assay, it was determined that both antioxidants protected DNA integrity and re- 
sulted in a lower percentage of sperm with damaged DNA than that of the controls $(\mathrm{P}<0.05)$ (Table 3$)$. In terms of biochemical assays, no significant difference was observed in LPO and AOP between groups $(\mathrm{P}>0.05)($ Table 4$)$.

\section{Table 1}

Sperm motility (mean \pm SEM) in frozen-thawed bull semen

\begin{tabular}{lccc}
\hline Groups & Subjective motility (\%) & CASA motility (\%) & Progressive motility \% \\
\hline Control & $43 \pm 2.73^{\mathrm{b}}$ & $55.4 \pm 6.78^{\mathrm{b}}$ & $33.48 \pm 4.14^{\mathrm{b}}$ \\
Arginine $2 \mathrm{mM}$ & $29 \pm 8.21^{\mathrm{a}}$ & $12.2 \pm 5.69^{\mathrm{a}}$ & $3.52 \pm 2.13^{\mathrm{a}}$ \\
Trehalose $25 \mathrm{mM}$ & $50 \pm 3.53^{\mathrm{b}}$ & $64.7 \pm 6.79^{\mathrm{b}}$ & $34.36 \pm 4.77^{\mathrm{b}}$ \\
\hline
\end{tabular}

$\mathrm{P}$

a,b,c Different superscripts within the same column demonstrate significant differences $\left({ }^{*} \mathrm{P}<0.05\right)$

Table 2

Sperm motion characteristics (mean $\pm \mathrm{SEM}$ ) in frozen-thawed bull semen

\begin{tabular}{lccccc}
\hline Groups & VAP & VSL & VCL & ALH & LIN \\
\hline Control & $74 \pm 6.74^{\mathrm{b}}$ & $59.5 \pm 6.06^{\mathrm{a}}$ & $105.7 \pm 9.44^{\mathrm{a}}$ & $3.86 \pm 0.42^{\mathrm{a}}$ & $56.3 \pm 1.71^{\mathrm{b}}$ \\
Arginine $2 \mathrm{mM}$ & $43.8 \pm 3.37^{\mathrm{a}}$ & $29.9 \pm 3.35^{\mathrm{b}}$ & $81.4 \pm 4.93^{\mathrm{b}}$ & $4.38 \pm 0.61^{\mathrm{a}}$ & $36.82 \pm 3.46^{\mathrm{a}}$ \\
Trehalose $25 \mathrm{mM}$ & $64.8 \pm 10.27^{\mathrm{b}}$ & $50.8 \pm 9.67^{\mathrm{a}}$ & $97.9 \pm 13.29^{\mathrm{ab}}$ & $3.8 \pm 0.31^{\mathrm{a}}$ & $51.76 \pm 4.44^{\mathrm{b}}$ \\
\hline $\mathrm{P}$ & $*$ & $*$ & $*$ & - & $*$
\end{tabular}

-: No significant difference; ${ }^{\text {a,b,c }}$ Different superscripts within the same column demonstrate significant differences $\left({ }^{*} \mathrm{P}<0.05\right)$

Table 3

Flourescent staining (mean \pm SEM) in frozen-thawed bull semen

\begin{tabular}{lcccc}
\hline Groups & $\begin{array}{c}\text { Acrosome integrity } \\
(\%)\end{array}$ & $\begin{array}{c}\text { High } \\
\text { mitochondrial } \\
\text { activity }(\%)\end{array}$ & $\begin{array}{c}\text { Sperm viability } \\
(\%)\end{array}$ & $\begin{array}{c}\text { Damaged DNA } \\
(\%)\end{array}$ \\
\hline Control & $43.5 \pm 4.46^{\mathrm{ab}}$ & $13 \pm 8.15^{\mathrm{a}}$ & $31.7 \pm 3.94^{\mathrm{a}}$ & $9.6^{\mathrm{a}}$ \\
Arginin 2 $\mathrm{mM}$ & $37.4 \pm 4.43^{\mathrm{a}}$ & $7.6 \pm 4.89^{\mathrm{a}}$ & $22.1 \pm 3.28^{\mathrm{b}}$ & $7.2^{\mathrm{b}}$ \\
Trehalose $25 \mathrm{mM}$ & $48.2 \pm 8.70^{\mathrm{b}}$ & $36.3 \pm 3.99^{\mathrm{b}}$ & $44.1 \pm 2.18^{\mathrm{c}}$ & $4.9^{\mathrm{c}}$ \\
\hline $\mathrm{P}$ & $*$ & $*$ & $*$ & $* *$
\end{tabular}

${ }^{\mathrm{a}, \mathrm{b}, \mathrm{c}}$ Different superscripts within the same column demonstrate significant differences ${ }^{*} \mathrm{P}<0.05$; $\left.{ }^{* *} \mathrm{P}<0.01\right)$

\section{Discussion}

Cryodamage to spermatozoa caused by the cryopreservation procedure results in impaired fertility and decreased survival of spermatozoa in the female reproductive system (Singh et al., 2012). 
Table 4

LPO $\left(\mu \mathrm{M} \times 10^{9}\right)$ and AOP $\left(\mathrm{mM} \times 10^{9}\right)$ levels $($ mean $\pm \mathrm{SEM})$ in frozen-thawed bull semen

\begin{tabular}{lcc}
\hline Groups & LPO $\left(\mu \mathrm{M} \times 10^{9}\right)$ & AOP $\left(\mathrm{mM} \times 10^{9}\right)$ \\
\hline Control & $19.47 \pm 7.36$ & $19.11 \pm 6.57$ \\
Arginin 2 $\mathrm{mM}$ & $19.41 \pm 8.16$ & $24.09 \pm 7.64$ \\
Trehalose $25 \mathrm{mM}$ & $19.82 \pm 8.96$ & $21.27 \pm 6.39$ \\
\hline P & - & - \\
\hline
\end{tabular}

-: No significant difference

This study investigated the protective effects of the antioxidants arginine and trehalose against cryoinjury by the evaluation of sperm and oxidative stress parameters following freezing and thawing of bull semen.

Membrane lipid peroxidation has been considered an important problem for sperm survival and fertility, and sperm motility is also inhibited by reactive oxygen species formation through decreased ATP production (Guthrie and Welch, 2012). Oxidative stress causes cellular damage when the production of ROS goes beyond the antioxidant capacity of the organism. ROS damage the sperm membrane and the DNA, which results in decreased sperm motility and reduced ability to fuse with the oocyte (Tremellen, 2008). Antioxidants scavenge free radicals and improve sperm parameters (Gharagozloo and Aitken, 2011).

Sperm freezing increases the percentage of DNA fragmentation. This effect occurs after cryopreservation and has been reported by several authors (Aitken et al., 1998; Thomson et al., 2009a). DNA fragmentation and oxidative DNA damage were found to be related to each other and they correlate with cryopreservation (Thomson et al., 2009b). Potts et al. (2000) has reported DNA damage in human spermatozoa connected with ROS and lipid peroxidation. Like in our study, Ogretmen et al. (2015) also reported that extenders with antioxidant additives had protective effects against sperm DNA damage resulting from cryopreservation.

Trehalose acts like a non-permeating cryoprotectant which causes dehydration of spermatozoa due to the osmotically driven flow of water. Due to this mild dehydration, spermatozoa have less intracellular water which results in reduced intracellular ice crystal formation. This is beneficial for sperm because intracellular ice crystal formation results in cell death and, consequently, reduced fertility of the cryopreserved semen (Chhillar et al., 2012). Supplementation of trehalose to the semen extender significantly improved sperm characteristics such as post-thaw motility, viability, and membrane integrity. The same results verify the findings of earlier studies using the same additive to the semen extender for improving sperm quality after cryopreservation (Reddy et al., 2010; Singh et al., 2012). Ram semen extender including trehalose $(100 \mathrm{mM})$ improved post-thaw 
membrane integrity but did not have any positive effect on sperm motility and morphology (Cirit et al., 2013). The addition of $50 \mathrm{mM}$ trehalose to the semen diluent (Tris-citric acid-egg yolk-fructose) had a beneficial effect in chilling bull semen: trehalose ameliorated motility, sperm membrane integrity (HOST), viability, abnormal morphology, and DNA fragmentation compared to control group (El-Sheshtawy et al., 2015). Trehalose is able to protect the DNA integrity of sperm cells and has a protective effect on chromatin status. Trehalose showed protective effects on sperm characteristics and acrosome integrity compared to the controls (Bhattacharyya et al., 2006). In the present study, $25 \mathrm{mM}$ trehalose caused a significant $(\mathrm{P}<0.05)$ increase in post-thaw sperm motility, viability, mitochondrial activity, and DNA integrity compared to the control group.

Patel et al. (1999) showed that L-arginine has an important role in male fertility and can be used in the treatment of male infertility. Arginine resulted in better post-thaw motility, viability, and membrane integrity in buffalo semen compared with those of the control group; in addition, arginine had a protective effect on LPO level compared to the control (Siddique and Atreja, 2013). Larginine protects sperm from lipid peroxidation by inhibiting the nitric oxide synthase enzyme (Srivastava et al., 2006). Total motility and hyperactivated cells were reduced at an L-arginine concentration of $10 \mathrm{mM}$, and such doses of Larginine were found to be harmful to sperm motility patterns in cryopreserved equine sperm (Carvalho et al., 2012). L-arginine is essential for sperm cells and it is useful for artificial insemination with subnormal human semen (Patel et al., 1998). O'Flaherty et al. (2004) suggested that L-arginine has a positive effect on bovine sperm function. This amino acid induces sperm capacitation and acrosome reaction without causing any change in the progressive motility and viability of bovine spermatozoa.

In the present study, it was concluded that trehalose provides a protective effect by improving the spermatological parameters and protecting DNA integrity. However, arginine worsened these parameters with the exception of DNA integrity. The use of extenders including trehalose sugars may be recommended to improve cryopreservation of bovine semen.

\section{References}

Aboagla, E. M. E. and Terada, T. (2003): Trehalose-enhanced fluidity of the goat sperm membrane and its protection during freezing. Biol. Reprod. 69, 1245-1250.

Aitken, R. J., De Iuliis, G. N. and McLachlan, R. I. (2009): Biological and clinical significance of DNA damage in the male germ line. Int. J. Androl. 32, 46-56.

Aitken, R. J., Gordon, E., Harkiss, D., Twigg, J. P., Milne, P., Jennings, Z. and Irvine, D. S. (1998): Relative impact of oxidative stress on the functional competence and genomic integrity of human spermatozoa. Biol. Reprod. 59, 1037-1046.

Bailey, J. L., Blodeau, J. F. and Cormier, N. (2000): Semen cryopreservation in domestic animals: A damaging and capacitating phenomenon - minireview. J. Androl. 21, 1-7. 
Berndtson, W. E. (2008): Comparative reliability and sensitivity of different methods for assessing treatment effects on sperm production. Anim. Reprod. Sci. 105, 5-22.

Bhattacharyya, A. K., Chakraborty, D., Varghese, A. C., Mukhopadhyay, D., Bhattacharya, J., Kundu, S. and Banerjee, A. (2006): Cryopreservation and post thaw motility, DNA integrity and acrosome status of pre-freeze prepared human semen in different trehalose concentrations. Hum. Reprod. 21, 150.

Carvalho, H. F., Silva, D. F., Andrade, A. F. C., Caldas-Bussiere, M. C., Celeghini, E. C. C., Alonso, M. A., Lemes, K. M., Florez-Rodriguez, S. A. and Arruda, R. P. (2012): Effect of different L-arginine concentrations on motility patterns and hyperactivation in cryopreserved equine sperm. J. Equine Vet. Sci. 32, 480-481.

Chhillar, S., Singh, V. K., Kumar, R. and Atreja, S. K. (2012): Effects of taurine or trehalose supplementation on functional competence of cryopreserved Karan Fries semen. Anim. Reprod. Sci. 135, 1-7.

Cirit, U., Bagis, H., Demir, K., Agca, C., Pabuccuoglu, S., Varisli, O., Clifford-Rathert, C. and Agca, Y. (2013): Comparison of cryoprotective effects of iodixanol, trehalose and cysteamine on ram semen. Anim. Reprod. Sci. 139, 38-44.

Crowe, J. H., Crowe, L. M., Carpenter, J. F. and Aurell Wistrom, C. (1987): Stabilization of dry phospholipid bilayers and proteins by sugars. Biochem. J. 242, 1-10.

Duty, S. M., Singh, N. P., Ryan, L., Chen, Z., Lewis, C., Huang, T. and Hauser, R. (2002): Reliability of the comet assay in cryopreserved human sperm. Hum. Reprod. 17, 1274-1280.

El-Sheshtawy, R. I., Sisy, G. A. and El-Nattat, W. S. (2015): Effects of different concentrations of sucrose or trehalose on the post-thawing quality of cattle bull semen. Asian Pac. J. Reprod. $4,26-31$.

Garde, J. J., Del Olmo, A., Soler, A. J., Espeso, G., Gomendio, M. and Roldan, E. R. S. (2008): Effect of egg yolk, cryoprotectant, and various sugars on semen cryopreservation in endangered Cuvier's gazelle (Gazella cuvieri). Anim. Reprod. Sci. 108, 384-401.

Garner, D. L. and Johnson, L. A. (1995): Viability assessment of mammalian sperm using SYBR14 and propidium iodide. Biol. Reprod. 53, 276-284.

Garner, D. L., Thomas, C. A., Joerg, H. W., Dejarnette, J. M. and Marshall, C. E. (1997): Fluorometric assessments of mitochondrial function and viability in cryopreserved bovine spermatozoa. Biol. Reprod. 57, 1401-1406.

Gharagozloo, P. and Aitken, R. J. (2011): The role of sperm oxidative stress in male infertility and the significance of oral antioxidant therapy. Hum. Reprod. 26, 1628-1640.

Gholami, H., Chamani, M., Towhidi, A. and Fazeli, M. H. (2010): Effect of feeding a docosahexaenoic acid-enriched nutriceutical on the quality of fresh and frozen-thawed semen in Holstein bulls. Theriogenology 74, 1548-1558.

Guthrie, H. D. and Welch, G. R. (2012): Effects of reactive oxygen species on sperm function. Theriogenology 78, 1700-1708.

Li, Z. X., Wang, T. T., Wu, Y. T., Xu, C. M., Dong, M. Y., Sheng, J. Z. and Huang, H. F. (2008): Adriamycin induces H2AX phosphorylation in human spermatozoa. Asian J. Androl. 10, 749-757.

Nagy, S., Jansen, J., Topper, E. K. and Gadella, B. M. (2003): A triple-stain flow cytometric method to assess plasma- and acrosome-membrane integrity of cryopreserved bovine sperm immediately after thawing in presence of egg-yolk particles. Biol. Reprod. 68, $1828-1835$.

O'Flaherty, C., Rodriguez, P. and Srivastava, S. (2004): L-arginine promotes capacitation and acrosome reaction in cryopreserved bovine spermatozoa. Biochim. Biophys. Acta 1674, 215-221.

Ogretmen, F., İnanan, B. E., Kutluyer, F. and Kayim, M. (2015): Effect of semen extender supplementation with cysteine on postthaw sperm quality, DNA damage, and fertilizing ability in the common carp (Cyprinus carpio). Theriogenology 83, 1548-1552.

Patel, A. B., Srivastava, S., Phadke, R. S. and Govil, G. (1998): Arginine activates glycolysis of goat epididymal spermatozoa: an NMR study. Biophys. J. 75, 1522-1528. 
Patel, A. B., Srivastava, S., Phadke, R. S. and Govil, G. (1999): Arginine acts as a protective and reversal agent against glycolytic inhibitors in spermatozoa. Physiol. Chem. Phys. Med. NMR 31, 29-40.

Potts, R. J., Notarianni, L. J. and Jefferies, T. M. (2000): Seminal plasma reduces exogenous oxidative damage to human sperm, determined by the measurement of DNA strand breaks and lipid peroxidation. Mutat. Res. 447, 249-256.

Reddy, N. S. S., Mohanarao, G. J. and Atreja, S. K. (2010): Effects of adding taurine and trehalose to a tris-based egg yolk extender on buffalo (Bubalus bubalis) sperm quality following cryopreservation. Anim. Reprod. Sci. 119, 183-190.

Sanocka, D. and Kurpisz, M. (2004): Reactive oxygen species and sperm cells. Reprod. Biol. Endocrinol. 2, 1-7.

Siddique, R. A. and Atreja, S. K. (2013): Effect of L-arginine and spermine-NONOate on motility, viability, membrane integrity and lipid peroxidation of Murrah buffalo (Bubalus bubalis) spermatozoa. Livestock Sci. 153, 147-153.

Singh, V. K., Atreja, S. K., Kumar, R., Chhillar, S. and Singh, A. K. (2012): Assessment of intracellular $\mathrm{Ca}^{2+}$, cAMP and 1,2-diacylglycerol in cryopreserved buffalo (Bubalus bubalis) spermatozoa on supplementation of taurine and trehalose in the extender. Reprod. Dom. Anim. 47, 584-590.

Srivastava, S., Desai, P., Coutinho, E. and Govil, G. (2006): Mechanism of action of L-arginine on the vitality of spermatozoa is primarily through increased biosynthesis of nitric oxide. Biol. Reprod. 74, 954-958.

Thomson, L. K., Fleming, S. D., Aitken, R. J., De Iuliis, G. N., Zieschang, J. A. and Clark, A. M. (2009b): Cryopreservation-induced human sperm DNA damage is predominantly mediated by oxidative stress rather than apoptosis. Hum. Reprod. 24, 2061-2070.

Thomson, L. K., Fleming, S. D., Schulke, L., Barone, K., Zieschang, J. A. and Clark, A. M. $(2009 a)$ : The DNA integrity of cryopreserved spermatozoa separated for use in assisted reproductive technology is unaffected by the type of cryoprotectant used but is related to the DNA integrity of the fresh separated preparation. Fertil. Steril. 92, 991-1001.

Tonieto, R. A., Goularte, K. L., Gastal, G. D. A., Schiavon, R. S., Deschamps, J. C. and Lucia, T. (2010): Cryoprotectant effect of trehalose and low-density lipoprotein in extenders for frozen ram semen. Small Rumin. Res. 93, 206-209.

Tremellen, K. (2008): Oxidative stress and male infertility - a clinical perspective. Hum. Reprod. Update 14, 243-258.

Wang, A. W., Zhang, H., Ikemoto, I., Anderson, D. J. and Loughlin, K. R. (1997): Reactive oxygen species generation by seminal cells during cryopreservation. Urology 49, 921-925. 